\title{
Effects of resynchronization programs on pregnancy per artificial insemination, progesterone, and pregnancy-associated glycoproteins in plasma of lactating dairy cows
}

\author{
I. M. Thompson, ${ }^{*}$ R. L. A. Cerri, ${ }^{*}$ I. H. Kim,† J. A. Green,ł J. E. P. Santos,, ${ }^{*}$ and W. W. Thatcher*1 \\ *Department of Animal Sciences, University of Florida, Gainesville 32611 \\ †Chungbuk National University, Cheongju Chungbuk 361-763, South Korea \\ $\ddagger$ Department of Animal Sciences, University of Missouri, Columbia 65211
}

\begin{abstract}
Objectives were to develop a timed artificial insemination (TAI) resynchronization program to improve pregnancy per AI and to evaluate responses of circulating progesterone and pregnancy-associated glycoproteins in lactating cows. Cows $(\mathrm{n}=1,578)$ were presynchronized with 2 injections of $\mathrm{PGF}_{2 \alpha}$, given $14 \mathrm{~d}$ apart starting on d $45 \pm 3$ postpartum, followed by Ovsynch [2 injections of GnRH $7 \mathrm{~d}$ before and $56 \mathrm{~h}$ after injection of $\mathrm{PGF}_{2 \alpha}$, TAI $16 \mathrm{~h}$ after second injection (d 0)]. The Resynch-treated cows received an intravaginal progesterone insert from d 18 to $25, \mathrm{GnRH}$ on d 25, and pregnancy diagnosis on $\mathrm{d} 32$, and nonpregnant cows received $\mathrm{PGF}_{2 \alpha}$. GnRH $56 \mathrm{~h}$ later, and TAI $16 \mathrm{~h}$ later (d 35). The control cows were diagnosed for pregnancy on d 32 and nonpregnant cows received $\mathrm{GnRH}, \mathrm{PGF}_{2 \alpha}$ $39 \mathrm{~d}$ after TAI, GnRH $56 \mathrm{~h}$ later, and TAI $16 \mathrm{~h}$ later (d 42). Pregnancy was reconfirmed on d 60 after AI. Ovarian structures were examined in a subset of cows at the time of $\mathrm{GnRH}$ and $\mathrm{PGF}_{2 \alpha}$ injections. Blood samples for analyses of progesterone and pregnancy-associated glycoproteins were collected every 2 d from d 18 to 30 in 100 cows, and collection continued weekly to $\mathrm{d} 60$ for pregnant cows $(n=43)$. Preenrollment pregnancies per AI on d 32 did not differ for cows subsequently treated as Resynch $(45.8 \%, \mathrm{n}=814)$ and control $(45.9 \%, \mathrm{n}=$ 764 ), and pregnancy losses on d 60 were 6.7 and $4.0 \%$, respectively. Resynchronized service pregnancy per AI $(36 \%, \mathrm{n}=441 ; 39.5 \%, \mathrm{n}=412)$ and pregnancy losses (6.3 and $6.7 \%$ ) did not differ for Resynch and control treatments, respectively. Days open for pregnant cows after 2 TAI were less for the Resynch treatment than for the control treatment $(96.2 \pm 0.82$ vs. $99.5 \pm 0.83$ d). Cows in the Resynch treatment had more large follicles at the time of $\mathrm{GnRH}$. The number of corpora lutea did not differ between treatments at the time of $\mathrm{PGF}_{2 \alpha}$. Plasma progesterone for pregnant cows was
\end{abstract}

Received November 24, 2009.

Accepted May 3, 2010.

${ }^{1}$ Corresponding author: thatcher@ufl.edu greater for Resynch cows than for control cows (18-60 d; 6.6 vs. $5.3 \mathrm{ng} / \mathrm{mL}$ ), and plasma concentrations of progesterone on d 18 were greater for pregnant cows than for nonpregnant cows (5.3 vs. $4.3 \mathrm{ng} / \mathrm{mL}$ ). Plasma pregnancy-associated glycoproteins during pregnancy were lower for cows in the Resynch treatment compared with control cows on d 39 (2.8 vs. $4.1 \mathrm{ng} / \mathrm{mL})$ and 46 (1.3 vs. $3.0 \mathrm{ng} / \mathrm{mL}$ ). Cows pregnant on $\mathrm{d} 32$ that lost pregnancy by d $60(n=7)$ had lower plasma concentrations of pregnancy-associated glycoproteins on d 30 than cows that maintained pregnancy $(\mathrm{n}=36 ; 2.9$ vs. $5.0 \mathrm{ng} / \mathrm{mL}$ ). Pregnancy-associated glycoproteins on $\mathrm{d}$ $30(>0.33 \mathrm{ng} / \mathrm{mL})$ were predictive of a positive $\mathrm{d} 32$ pregnancy diagnosis (sensitivity $=100 \%$; specificity $=$ $90.6 \%$ ). In conclusion, Resynch and control protocols had comparable pregnancy per AI for first and second TAI services, but pregnancy occurred $3.2 \mathrm{~d}$ earlier in the Resynch group because inseminations in the Resynch treatment began $7 \mathrm{~d}$ before those in the control treatment. Administration of an intravaginal progesterone insert, or GnRH, or both increased progesterone during pregnancy. Dynamics of pregnancy-associated glycoproteins were indicative of pregnancy status and pregnancy loss.

Key words: resynchronization, progesterone, pregnancy-associated glycoprotein

\section{INTRODUCTION}

Accurate and early detection of nonpregnant cows combined with a program for resynchronization of ovulation will improve reproductive efficiency of dairy herds. Acceptable pregnancy per AI has been achieved with the use of ovulation synchronization programs for timed AI (TAI) to maximize submission rates for insemination at the designated voluntary waiting period (Chebel et al., 2006).

A presynchronization protocol with 2 injections of $\mathrm{PGF}_{2 \alpha}$ administered $14 \mathrm{~d}$ apart and initiation of the Ovsynch protocol (Pursley et al., 1997) 12 d later (Moreira et al., 2001) increased pregnancy per AI to first service in lactating dairy cows. Cows diagnosed non- 
pregnant after a Presynch + Ovsynch and TAI should be resynchronized as early as possible when diagnosed nonpregnant. Protocols for resynchronization of ovulation (Resynch) can increase the effective AI service rate and reduce the interval between AI services (Fricke, 2002). Programming the stage of the estrous cycle for resynchronization after the initial TAI is a physiological approach to reducing the interval between TAI services (Bartolome et al., 2005a,b,c).

The measurement of pregnancy-associated glycoproteins (PAG) as an indicator of early pregnancy in cattle can serve as a tool to help optimize reproductive management (Sasser et al., 1986; Zoli et al., 1992; Green et al., 2005). Furthermore, monitoring the circulating concentration of PAG also can assist in identification of embryo or fetal well-being and pregnancy loss (Patel et al., 1997; Kornmatitsuk et al., 2002; Gábor et al., 2007).

Objectives of this study were to 1) characterize pregnancy per AI for first and second services in cows receiving a Presynch + Ovsynch and an intravaginal progesterone insert (CIDR) resynchronization program (Resynch) compared with those receiving a Presynch + Ovsynch and a control resynchronization program (control), and 2) compare concentrations of progesterone and PAG after first insemination between d 18 and 60 for pregnant cows and between d 18 and 30 for nonpregnant cows of the Resynch and control programs.

\section{MATERIALS AND METHODS}

\section{Study Population}

The study was conducted from October 2007 to July 2008 in a large commercial dairy of north central Florida with 3,900 milking cows. A total of 1,772 primiparous and multiparous lactating dairy cows were enrolled. Cows were housed in free stall barns and fed a TMR with ad libitum access to feed and water. Diets were formulated to meet NRC (2001) nutrient requirements for $\mathrm{NE}_{\mathrm{L}}$, CP, fiber, minerals, and vitamins for postpartum cows. Cows were milked thrice daily; 305-d mature equivalent milk production for primiparous and multiparous cows was 11,878 and $11,922 \mathrm{~kg}$, respectively.

\section{Study Design}

Multiparous cows were scheduled to receive initial hormonal injections on Mondays and TAI on Thursdays. Primiparous cows received hormonal injections on Tuesdays and were scheduled to receive TAI on Fridays. All cows were submitted to a Presynch + Ovsynch protocol. Presynch [i.e., 2 intramuscular injections of $\mathrm{PGF}_{2 \alpha}$ (25 mg; Lutalyse, Pfizer Animal Health, New York, NY) given $14 \mathrm{~d}$ apart] was initiated at $45 \pm 3 \mathrm{~d}$ after parturition. At $14 \mathrm{~d}$ after the second $\mathrm{PGF}_{2 \alpha}$ injection of Presynch, Ovsynch was initiated by administering 2 injections of GnRH (100 $\mu \mathrm{g}$; Cystorelin, Merial Ltd., Duluth, GA) $7 \mathrm{~d}$ before and $56 \mathrm{~h}$ after injection of $\mathrm{PGF}_{2 \alpha}(25 \mathrm{mg})$, and cows were TAI $16 \mathrm{~h}$ after the second GnRH injection. Of the 1,772 cows enrolled, 194 $(10.9 \%)$ were excluded because they were sold, died, or failed to complete the hormonal injection sequences for the Presynch + Ovsynch or Resynch protocols. Thus, a total of 1,578 cows completed the study (Figure 1).

\section{Resynchronization Treatments}

Primiparous and multiparous cows were managed in separate pens and assigned to 2 resynchronization treatments after calving (Resynch and control) based upon odd and even last numbers of the ear tags. Cows in the Resynch treatment $(\mathrm{n}=441)$ received a CIDR (Pfizer Animal Health) for $7 \mathrm{~d}$ starting on d 18 after TAI. Cows received an intramuscular injection of $\mathrm{GnRH}$ $(100 \mu \mathrm{g})$ at the time that the CIDR insert was removed on d 25 after TAI. Pregnancy status was assessed 7 d later on d 32 after TAI by ultrasonography (EasiScan, BCF Technology, Rochester, MN). The presence of an embryo with a heartbeat was the criterion used to determine pregnancy. Cows diagnosed pregnant were reexamined by palpation per rectum of the uterus and its contents on d 60 after TAI to reconfirm pregnancy status and quantify pregnancy loss. Nonpregnant cows continued Resynch by receiving an intramuscular injection of $25 \mathrm{mg}$ of $\mathrm{PGF}_{2 \alpha}$ on d 32 after TAI followed by a GnRH injection $(100 \mu \mathrm{g}) 56 \mathrm{~h}$ after the $\mathrm{PGF}_{2 \alpha}$ injection. All nonpregnant cows were TAI $16 \mathrm{~h}$ after the $\mathrm{GnRH}$ injection. Pregnancy diagnosis by ultrasonography was conducted $32 \mathrm{~d}$ after the second TAI and pregnancy was reconfirmed at $60 \mathrm{~d}$ (Figure 1).

Cows assigned to the control treatment $(\mathrm{n}=413)$ underwent ultrasonography on d 32 after TAI to determine pregnancy status. Pregnant cows had pregnancy reconfirmed on d 60 after TAI. All nonpregnant cows received an injection of GnRH on d 32 followed by an intramuscular injection of $\mathrm{PGF}_{2 \alpha}(25 \mathrm{mg})$ on d 39 after TAI, a GnRH injection $(100 \mu \mathrm{g}) 56 \mathrm{~h}$ later, and TAI 72 $\mathrm{h}$ after $\mathrm{PGF}_{2 \alpha}$. The second service pregnancy diagnosis by ultrasound was conducted $32 \mathrm{~d}$ after TAI and pregnancy was reconfirmed on d 60 (Figure 1).

\section{Ovarian Ultrasonography}

Following first service pregnancy diagnosis (d 32), all cows enrolled in the experiment $(\mathrm{n}=1,578)$ had 


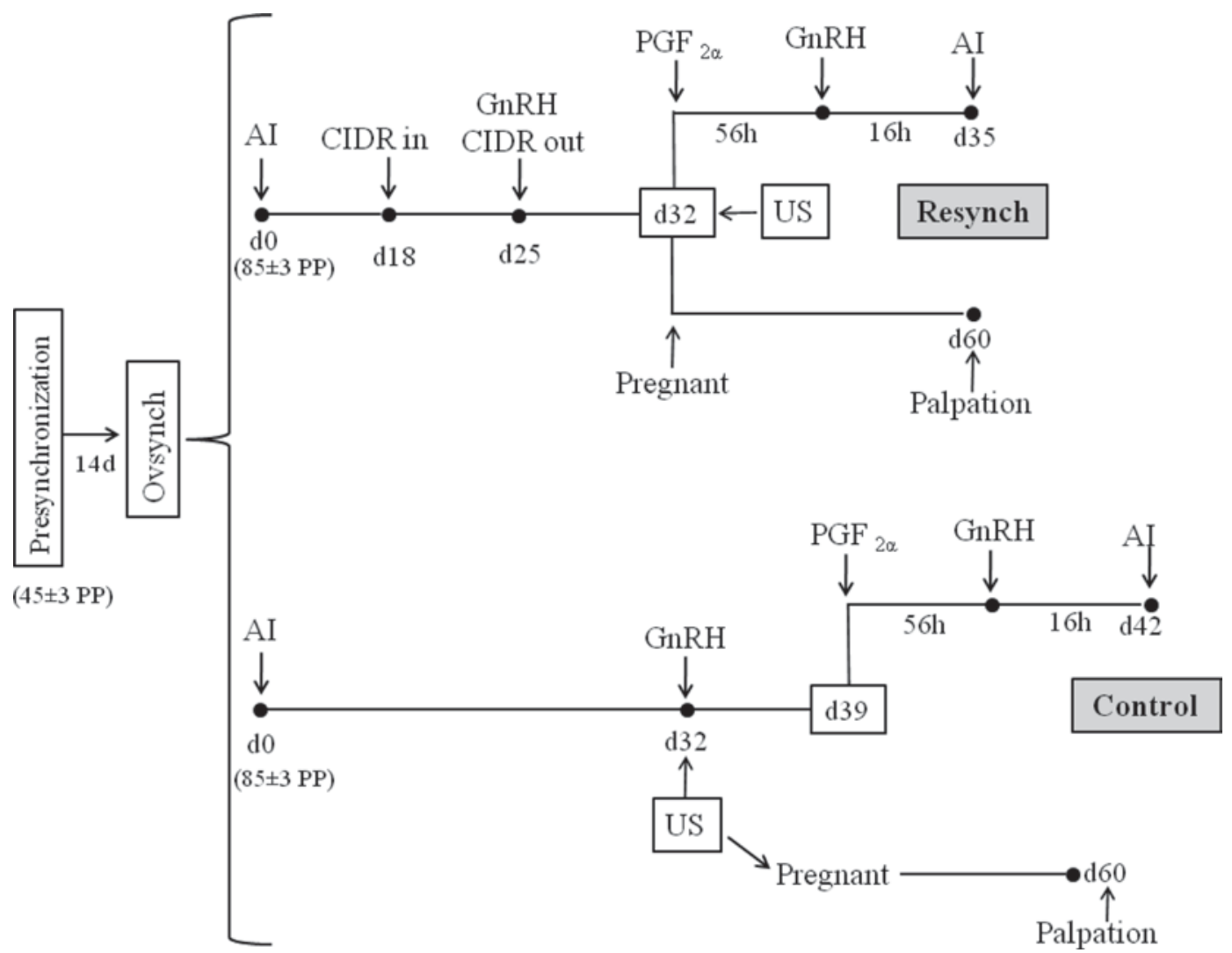

Figure 1. Experimental design. $\mathrm{PP}=$ days postpartum; CIDR = controlled internal drug releasing device containing progesterone; $\mathrm{GnRH}=$ injection of $\mathrm{GnRH} ; \mathrm{PGF}_{2 \alpha}=$ injection of $\mathrm{PGF}_{2 \alpha}$; Ovsynch = protocol for synchronization of ovulation; US = ultrasonographic examination.

their ovaries checked by ultrasound for the presence or absence of corpus luteum $(\mathbf{C L})$ regardless of whether the cows were pregnant or nonpregnant. Ovarian ultrasound examinations were performed on a subgroup of cows $(\mathrm{n}=149)$ of both resynchronization treatments at the time of $\mathrm{GnRH}$ and $\mathrm{PGF}_{2 \alpha}$ injections. Presence of CL and follicle sizes were recorded.

\section{PAG Blood Collection and ELISA Assay}

Blood samples for measurement of PAG were collected from a subgroup of cows $(n=100)$ from both resynchronization programs. Samples were collected between d 18 and 60 after first AI for pregnant cows and between d 18 and 30 after first AI for nonpregnant cows. Sampling was every other day from d 18 to 30 and once weekly from d 32 to 60 after TAI. Additional blood samples for measurement of PAG were collected from a subgroup of cows $(\mathrm{n}=103)$ on the day of parturition. Samples were collected from the coccygeal blood vessels into evacuated tubes containing EDTA $(10 \mathrm{~mL}$ Vacutainer; Becton Dickinson, Franklin Lakes, NJ) and placed on ice immediately after collection. Samples were centrifuged for $30 \mathrm{~min}$, and plasma was stored at $-20^{\circ} \mathrm{C}$ until assayed for PAG.

Blood samples were analyzed for concentrations of PAG using a "sandwich" ELISA assay performed as described previously (Green et al., 2005), with some modifications. Specifically, a different detection rabbit polyclonal antibody (Ab20) was employed. This antibody was raised against a mixture of PAG that had been isolated based on its affinity toward the aspartic peptidase inhibitor pepstatin A. Late pregnant (third trimester) cotyledons from a twin pregnancy were homogenized, and PAG were obtained after binding to pepstatin-agarose under neutral $(\mathrm{pH} 7)$ and acidic $(\mathrm{pH}$ 5) conditions. Elution of PAG from the matrix was performed by increasing the osmolarity and $\mathrm{pH}$. Detailed methods describing PAG purification in this manner have been reported elsewhere (Green et al., 2005; Wooding et al., 2005; Green and Roberts, 2006). The eluted PAG were further enriched by binding and eluting them from an anion exchange matrix (MonoQ; BioRad, Hercules, CA). Binding was at $\mathrm{pH} 7.5$ in 20 $\mathrm{m} M$ Tris buffer; elution of PAG was between 0.1 and $0.2 \mathrm{M} \mathrm{NaCl}$. 
The Ab20 Ig were isolated by protein A affinity chromatography (Green et al., 2005; Green and Roberts, 2006) and further purified by binding and elution from a PAG matrix. Briefly, $1 \mathrm{mg}$ of the PAG mixture was biotinylated by conjugation to NHS LC-LC biotin (cat. no. 21343; Pierce, Rockford, IL). The final molar ratio of biotin to PAG was 20:1. The conjugation reaction was allowed to proceed for $3 \mathrm{~h}$ at room temperature on a rotator-mixer. The PAG-biotin conjugate was then dialyzed overnight $(50,000$ molecular weight cutoff) against Tris-buffered saline $(10 \mathrm{~m} M$ Tris, $\mathrm{pH} 8.0$; $150 \mathrm{mM} \mathrm{NaCl}$ ). The biotinylated PAG was added to $1 \mathrm{~mL}$ of an avidin-agarose slurry (cat. no. A2010; Vector Laboratories, Burlingame, CA) and agitated for 2 $\mathrm{h}$ on a rotator-mixer. The matrix was washed several times with PBS and then equilibrated in Tris-buffered saline. Purified Ab20 Ig was applied to the PAG-avidin matrix, washed with Tris-buffered saline (30 column volumes), and then eluted with $0.1 M$ glycine, $\mathrm{pH} 2.0$, followed by a $0.5 \mathrm{M}$ glycine, $\mathrm{pH} 2.0$ elution. The eluted fractions were neutralized with $1 M$ Tris, $\mathrm{pH} 9.5$, and dialyzed against PBS. The anti-PAG immunoglobulin was concentrated by using an Amicon Ultra device (UFC903024, Millipore, Billerica, MA) and quantified by bicinchoninic acid assay with rabbit IgG as standard. The purified Ab20 was used as the detection antibody in the ELISA at $0.1 \mu \mathrm{g} /$ well, which differed from the previous assay format that used $1 \mu \mathrm{g} /$ well (Green et al., 2005).

The PAG ELISA was performed as described previously (Green et al., 2005). Pooled error variance of the duplicates of 331 samples gave a coefficient of variation of $22.3 \%$. Inter- and intraassay coefficients of variation for replicates run in 3 assays for d 28 of pregnancy were 11.8 and $14.6 \%$, respectively, and for d 41 were 9.3 and $16.3 \%$, respectively.

\section{Plasma Progesterone Concentrations}

Measurement of plasma progesterone concentrations was performed from the same blood samples used for the measurement of PAG. The samples were obtained from the coccygeal vessels into evacuated tubes containing EDTA (10 mL Vacutainer; Becton Dickinson) and placed on ice immediately after collection. Samples were centrifuged for $30 \mathrm{~min}$, and plasma was stored at $-20^{\circ} \mathrm{C}$. Plasma concentrations of progesterone were determined by a solid-phase, no extraction RIA (Coat-ACount Progesterone, DPC Diagnostic Products Corp., Los Angeles, CA). The procedure has been previously validated by our laboratory (Garbarino et al., 2004). The standard curve dilution consisted of duplicated plain tubes used for total counts and nonspecific binding. A $100-\mu \mathrm{L}$ aliquot of increasing progesterone con- centrations of calibrators $(0.1,0.25,0.5,1,2,5,10$, and $20 \mathrm{ng} / \mathrm{mL}$ ) was added to the tubes. The sensitivity of the assay was $0.1 \mathrm{ng} / \mathrm{mL}$. The intra- and interassay coefficients of variation for the replicates ran in each assay for plasma on $\mathrm{d} 4$ of the cycle $(1.27 \pm 0.04$ $\mathrm{ng} / \mathrm{mL}$ ) were 8.1 and $10.2 \%$, respectively, and for $\mathrm{d} 8$ of the cycle $(4.14 \pm 0.05 \mathrm{ng} / \mathrm{mL})$ were 2.8 and $5.3 \%$, respectively.

\section{Statistical Analyses}

The proportions of pregnant cows (pregnancies per TAI) to first and second services were analyzed by logistic regression using PROC LOGISTIC of SAS (version 9.1, SAS Institute Inc., Cary, NC). The model for pregnancies per TAI for the first and second services included the effects of 2 different reproductive management treatments (control vs. Resynch), parity (primiparous vs. multiparous), sires, inseminators, occurrence of different clinical disorders (i.e., digestive problems, mastitis, dystocia, retained fetal membranes, displaced abomasums, ketosis, respiratory problems), and mean monthly milk weights for the first 3 mo of lactation (i.e., assigned to quartiles). Original modeling was performed using backward stepwise selection with the significance level for retention in the model set at $\alpha$ $\leq 0.10$. A subsequent logistic regression model was run including only variables that had a $P$-value $\leq 0.10$ from the backward stepwise logistic regression analysis. The model fit statistics were performed by comparison of the difference in the deviances by likelihood-ratio statistic test. Differences in frequency and proportion of ovarian structures (presence or absence of CL, number of CL and small, medium and large follicles) between treatments were analyzed by a multinomial logistic regression model using GLogit from SAS. In the model, one category of the dependent variable is chosen as the comparison category. The least squares means for number of CL for each treatment were obtained using the GLIMMIX procedure for generalized linear mixed models from SAS. The progesterone and PAG responses between resynchronization treatments were analyzed using repeated measures analyses of the MIXED procedure of SAS. Days open were calculated using the GLM procedure of SAS. The ability of the PAG ELISA assay to identify pregnant cows (sensitivity) and the ability to identify open cows (specificity) were tested by running a receiver operating characteristic curve for concentrations of PAG on d 28 and 30 of pregnancy.

\section{RESULTS}

\section{Breeding and Fertility}

Reproductive outcomes for first and second services are summarized in Table 1. No difference in pregnancy 
Table 1. Pregnancy rates at 32 and $60 \mathrm{~d}$ after first and second service timed artificial inseminations (TAI) for all experimental cows according to resynchronization treatments ${ }^{1}$

\begin{tabular}{lccccc}
\hline \multirow{2}{*}{ Item } & \multicolumn{2}{c}{ Resynch } & & \multicolumn{2}{c}{ Control } \\
\cline { 2 - 3 } \cline { 5 - 6 } & First TAI & Second TAI & & First TAI & Second TAI \\
\hline Pregnancy/TAI 32 d, \% (n/n) & $45.8(373 / 814)$ & $36.0(159 / 441)$ & & $45.9(351 / 764)$ & $39.5(163 / 413)$ \\
Pregnancy/TAI 60 d, \% (n/n) & $42.7(348 / 814)$ & $33.8(149 / 441)$ & & $44.1(337 / 764)$ & $36.9(152 / 412)$ \\
Pregnancy losses 32 to 60 d, \% (n/n) & $6.7(25 / 373)$ & $6.3(10 / 159)$ & & $4.0(14 / 351)$ & $6.7(11 / 163)$ \\
\hline
\end{tabular}

${ }^{1}$ Resynch treatment: cows received a controlled internal drug releasing device containing progesterone (CIDR) inserted for $7 \mathrm{~d}$ starting on d 18 after TAI and began an Ovsynch protocol beginning on d 25 at the time of CIDR removal. Only nonpregnant cows completed the protocol following a $\mathrm{PGF}_{2 \alpha}$ injection on $\mathrm{d} 32$ after TAI, a GnRH injection $56 \mathrm{~h}$ later, and TAI $72 \mathrm{~h}$ after $\mathrm{PGF}_{2 \alpha}$. Control treatment: nonpregnant cows began an Ovsynch protocol on d 32 after first TAI followed by an intramuscular injection of $\mathrm{PGF}_{2 \alpha}$ on d 39 after TAI, a $\mathrm{GnRH}$ injection $56 \mathrm{~h}$ later, and TAI $72 \mathrm{~h}$ after $\mathrm{PGF}_{2 \alpha}$.

per AI at first service was found between the Resynch and the control cows on $\mathrm{d} 32(P<0.90)$ and $\mathrm{d} 60(P<$ $0.54)$ of pregnancy. The overall first service pregnancies per AI were $45.9 \%$ on d 32 and $43.4 \%$ on d 60 ( $\mathrm{n}=$ $1,578)$.

The second service pregnancies per AI were $37.7 \%$ on $\mathrm{d} 32(\mathrm{n}=322)$ and $35.3 \%$ on $\mathrm{d} 60(\mathrm{n}=301)$ after second insemination and did not differ between treatments (Table 1). In addition, the overall pregnancy losses were 5.4 and $6.5 \%$ for first and second services. Pregnant Resynch cows averaged fewer $(P<0.01)$ days open (i.e., days between calving and conception) than control cows $(96.2 \pm 0.82$ vs. $99.5 \pm 0.83 \mathrm{~d})$.

Occurrence of different health disorders had an effect on pregnancy per AI on d 32 after first TAI. Cows that developed digestive problems $(13.9 \% ; \mathrm{n}=219)$ had a decrease $(P<0.01)$ in pregnancy per AI from $47.2 \%$ (healthy animals) to $37.9 \%$. The frequency of mastitis of the study population was $24.1 \%(\mathrm{n}=380)$, with a decrease $(P<0.06)$ in pregnancy per AI from 47.4 to $41.3 \%$. Occurrence of dystocia (i.e., considerable force and extreme difficulty; $3.4 \% ; \mathrm{n}=55)$ and retained fetal membranes (i.e., present $24 \mathrm{~h}$ after parturition; 5.5\%; $\mathrm{n}=88)$ also affected pregnancies per AI from 46.9 to $27.2 \%(P<0.005)$ and from 46.5 to $34 \%(P<0.06)$, respectively.

\section{Ovarian Ultrasonography}

Ovarian responses at the time of $\mathrm{GnRH}$ and $\mathrm{PGF}_{2 \alpha}$ injections for a subgroup of cows in both treatments are depicted in Tables 2, 3, and 4. Presence of CL and follicle sizes were recorded. Follicles were classified according to their diameter as small $(<10 \mathrm{~mm})$, medium (10-15 mm), and large $(>15 \mathrm{~mm})$. At the time of GnRH injection, fewer $(P<0.01) \mathrm{CL}$ were detected in nonpregnant Resynch cows than in nonpregnant control cows (0.61 vs. 0.92; Table 2). There was also a difference in occurrence of cows with no CL versus 1 CL between treatments $(P<0.01)$. Odds of cows having no CL versus $1 \mathrm{CL}$ in the Resynch treatment were 3.73 times greater than in the control treatment (Table 2). Average number of medium and large follicles per Resynch cow was greater than that per control cow (1.16 vs. $0.94 ; P<0.04)$. At the time of GnRH injection, a greater proportion of cows had a large follicle in the Resynch treatment than in the control treatment (77.1 vs. $35.4 \% ; P<0.01$; Table 3 ). The mean number of CL at the time of $\mathrm{PGF}_{2 \alpha}$ injection was not different between the control and Resynch treatments (0.88 vs. $0.82 ; P<$ 0.32). In contrast, the occurrence of a CL with a large follicle was less for the Resynch treatment compared with the control treatment $(P<0.01)$ at the time of $\mathrm{PGF}_{2 \alpha}$ injection (11.4 vs. $40.5 \%$; Table 4$)$. At the time of a nonpregnancy diagnosis for both resynchronization treatments on d 32, cows in the Resynch treatment to receive $\mathrm{PGF}_{2 \alpha}$ had the same proportion of $\mathrm{CL}$ as the cows in the control treatment to receive $\mathrm{GnRH}$ (81.4 vs. $81.1 \%$ ), a lesser occurrence of a CL + large follicle (11.4 vs. $26.5 \% ; P<0.01$ ), and a lesser occurrence of ovaries with a large follicle (17.0 vs. $35.4 \% ; P<0.01)$. Average number of medium and large follicles per cow did not differ between Resynch and control treatments (0.95 vs. 0.97). The presence or absence of a CL was recorded for all nonpregnant cows following first service in the experiment $(\mathrm{n}=854$; Table 5$)$, with cows in the Resynch treatment having a slightly greater occurrence of a CL $(80.0$ vs. $73.3 \%$ : $P<0.02)$.

\section{PAG}

Overall concentrations of PAG in plasma did not differ $(P<0.30)$ between treatments for pregnant cows (Resynch: $1.68 \pm 0.27 \mathrm{ng} / \mathrm{mL}, \mathrm{n}=20$; control: 2.07 $\pm 0.25 \mathrm{ng} / \mathrm{mL}, \mathrm{n}=23)$. In contrast, concentrations of PAG (Figure 2) were lesser in the Resynch treatment compared with the control treatment on d 39 (2.80 \pm 0.46 vs. $4.13 \pm 0.44 \mathrm{ng} / \mathrm{mL} ; P<0.04)$ and $\mathrm{d} 46(1.34$ 
Table 2. Effect of resynchronization treatments on the distribution of nonpregnant cows with either no, 1, or 2 corpus luteum (CL) at the time of GnRH injection on d 25 for Resynch and d 32 for control treatments

\begin{tabular}{|c|c|c|c|c|c|}
\hline \multirow[b]{2}{*}{ Treatment $^{1}$} & \multicolumn{3}{|c|}{ CL, \% (n) } & \multirow[b]{2}{*}{ Mean $^{3}$} & \multirow{2}{*}{$\begin{array}{c}\text { Total } \\
\text { cows }(\mathrm{n})\end{array}$} \\
\hline & No $\mathrm{CL}^{2}$ & $1 \mathrm{CL}^{2}$ & $2 \mathrm{CL}$ & & \\
\hline $\begin{array}{l}\text { Control } \\
\text { Resynch }\end{array}$ & $\begin{array}{l}18.9(15) \\
48.5(34)\end{array}$ & $\begin{array}{l}70.8(56) \\
48.5(34)\end{array}$ & $\begin{array}{r}10.1(8) \\
2.8(2)\end{array}$ & $\begin{array}{l}0.92^{\mathrm{a}} \\
0.61^{\mathrm{b}}\end{array}$ & $\begin{array}{l}79 \\
70\end{array}$ \\
\hline \multicolumn{6}{|c|}{$\begin{array}{l}\mathrm{a}, \mathrm{b} \text { Means within a column with different superscripts differ }(P<0.01) \text {. } \\
{ }^{1} \text { Control treatment: nonpregnant cows began an Ovsynch protocol on d } 32 \text { after first TAI followed by an in- } \\
\text { tramuscular injection of } \mathrm{PGF}_{2 \alpha} \text { on } \mathrm{d} 39 \text { after TAI, a GnRH injection } 56 \mathrm{~h} \text { later, and TAI } 72 \mathrm{~h} \text { after PGF } \mathrm{PG}_{2 \alpha} \text {. } \\
\text { Resynch treatment: cows received a controlled internal drug releasing device containing progesterone }(\mathrm{CIDR}) \\
\text { inserted for } 7 \mathrm{~d} \text { starting on } \mathrm{d} 18 \text { after TAI and began an Ovsynch protocol beginning on } \mathrm{d} 25 \text { at the time of } \\
\text { CIDR removal. Only nonpregnant cows completed the protocol following a PGF } \mathrm{PG}_{2 \alpha} \text { injection on d } 32 \text { after TAI, } \\
\text { a GnRH injection } 56 \mathrm{~h} \text { later, and TAI } 72 \mathrm{~h} \text { after } \mathrm{PGF}_{2 \alpha} \text {. } \\
{ }^{2} \mathrm{CL}(1 \mathrm{CL} \text { vs. no CL) } \times \text { treatment interaction; odds ratio: } 3.73 ; 95 \% \mathrm{CI}: 1.778-7.841 ; P \text {-value for no CL: } \\
<0.01 \text {. }\end{array}$} \\
\hline
\end{tabular}

\pm 0.46 vs. $3.03 \pm 0.44 \mathrm{ng} / \mathrm{mL} ; P<0.01)$. The profiles of PAG concentrations in the plasma of 43 pregnant cows (Figure 3) revealed that pregnant cows $(\mathrm{n}=36)$ maintaining pregnancy had greater $(P<0.05)$ plasma concentrations of PAG on d 30 after AI compared with cows undergoing late embryo mortality (LEM; $\mathrm{n}=7$ ) between $\mathrm{d} 32$ and 60 of pregnancy ( $4.98 \pm 0.42$ vs. 2.91 $\pm 0.96 \mathrm{ng} / \mathrm{mL}$ ). The sensitivity for diagnosis of pregnancy on d 28 was $95.3 \%$, with a specificity of $88.3 \%$, when concentrations of PAG were $>0.41 \mathrm{ng} / \mathrm{mL}$ for a diagnosis of pregnancy. On d 30 of pregnancy, sensitivity and specificity were 100 and $90.6 \%$, respectively, when cows with plasma concentrations $>0.33 \mathrm{ng} / \mathrm{mL}$ were considered pregnant.

Plasma concentrations of PAG on the day of parturition did not differ between treatments and were not associated with parity, calving difficulty, or occurrence of peripartum health disorders. In contrast, cows that delivered female calves had lesser $(P<0.05)$ plasma concentrations of PAG on the day of parturition compared with cows that delivered male calves (327.8 \pm 26.54 vs. $395.2 \pm 21.64 \mathrm{ng} / \mathrm{mL}$ ).

\section{Progesterone}

Pregnant Resynch cows maintained greater $(P<$ 0.003 ) progesterone concentrations than control cows even after removal of the CIDR insert (Figure 4). The mean concentrations of progesterone for the Resynch and control treatments were $6.59 \pm 0.30$ and $5.30 \pm$ $0.28 \mathrm{ng} / \mathrm{mL}$, respectively. All cows diagnosed pregnant on $\mathrm{d} 32(\mathrm{n}=36)$ had greater concentrations of plasma progesterone $(P<0.02)$ than nonpregnant cows with a CL $(\mathrm{n}=35)$ when sampled on d $18(5.26 \pm 0.30$ vs. $4.31 \pm 0.30 \mathrm{ng} / \mathrm{mL})$. In nonpregnant cows $(\mathrm{n}=57)$, there were no main effects of treatment and day on plasma concentrations of progesterone. In contrast, an interaction of treatment by day was detected $(P<0.03$;

Table 3. Effect of resynchronization treatments on the distribution of small $(<10 \mathrm{~mm})$, medium $(10-15 \mathrm{~mm})$, and large $(>15 \mathrm{~mm})$ follicles in nonpregnant cows at the time of GnRH injection on d 25 for Resynch and d 32 for control treatments

\begin{tabular}{|c|c|c|c|c|c|}
\hline \multirow[b]{2}{*}{ Treatment $^{1}$} & \multicolumn{3}{|c|}{ Follicle, \% (n) } & \multirow[b]{2}{*}{ Mean $^{3}$} & \multirow{2}{*}{$\begin{array}{c}\text { Total } \\
\text { cows }(\mathrm{n})\end{array}$} \\
\hline & Small & Medium $^{2}$ & Large $^{2}$ & & \\
\hline Control & $14(11)^{3}$ & $58.2(46)$ & $35.4(28)$ & $0.94^{\mathrm{a}}$ & 79 \\
\hline Resynch & $5.7(4)$ & $38.5(27)$ & $77.1(54)$ & $1.16^{\mathrm{b}}$ & 70 \\
\hline
\end{tabular}

a,b Means within a column with different superscripts differ $(P<0.05)$.

${ }^{1}$ Control treatment: nonpregnant cows began an Ovsynch protocol on d 32 after first TAI followed by an intramuscular injection of $\mathrm{PGF}_{2 \alpha}$ on d 39 after TAI, a GnRH injection $56 \mathrm{~h}$ later, and TAI $72 \mathrm{~h}$ after $\mathrm{PGF}_{2 \alpha}$. Resynch treatment: cows received a controlled internal drug releasing device containing progesterone (CIDR) inserted for $7 \mathrm{~d}$ starting on d 18 after TAI and began an Ovsynch protocol beginning on d 25 at the time of CIDR removal. Only nonpregnant cows completed the protocol following a PGF $_{2 \alpha}$ injection on d 32 after TAI, a GnRH injection $56 \mathrm{~h}$ later, and TAI $72 \mathrm{~h}$ after $\mathrm{PGF}_{2 \alpha}$.

${ }^{2}$ Follicles (medium vs. large) $\times$ treatment interaction; odds ratio: 3.29 ; $95 \%$ CI: $1.700-6.350$; $P$-value for medium: $<0.01$.

${ }^{3}$ Least squares means for number of medium and large follicles per treatment. 
Table 4. Effect of resynchronization treatments on distribution of nonpregnant cows with no corpus luteum (CL), CL, or CL + large follicle $(>15 \mathrm{~mm})$ at the time of $\mathrm{PGF}_{2 \alpha}$ injection on d 32 for Resynch and $\mathrm{d} 39$ for control treatments

\begin{tabular}{lccccc}
\hline Treatment $^{1}$ & $\begin{array}{c}\text { No CL, } \\
\%(\mathrm{n})\end{array}$ & $\begin{array}{c}\text { CL, } \\
\%(\mathrm{n})\end{array}$ & $\begin{array}{c}\text { CL + large } \\
\text { follicle, }{ }^{2} \%(\mathrm{n})\end{array}$ & Mean $^{3}$ & $\begin{array}{c}\text { Total } \\
\text { cows (n) }\end{array}$ \\
\hline Control & $12.6(10)$ & $46.8(37)$ & $40.5(32)$ & 0.88 & 79 \\
Resynch & $18.5(13)$ & $70.0(49)$ & $11.4(8)$ & 0.82 & 70 \\
\hline
\end{tabular}

${ }^{1}$ Control treatment: nonpregnant cows began an Ovsynch protocol on d 32 after first TAI followed by an intramuscular injection of $\mathrm{PGF}_{2 \alpha}$ on d 39 after TAI, a GnRH injection $56 \mathrm{~h}$ later, and TAI $72 \mathrm{~h}$ after $\mathrm{PGF}_{2 \alpha}$. Resynch treatment: cows received a controlled internal drug releasing device containing progesterone (CIDR) inserted for $7 \mathrm{~d}$ starting on d 18 after TAI and began an Ovsynch protocol beginning on d 25 at the time of CIDR removal. Only nonpregnant cows completed the protocol following a $\mathrm{PGF}_{2 \alpha}$ injection on d 32 after TAI, a GnRH injection $56 \mathrm{~h}$ later, and TAI $72 \mathrm{~h}$ after $\mathrm{PGF}_{2 \alpha}$.

${ }^{2} \mathrm{CL}$ vs. CL + large follicle $\times$ treatment interaction; odds ratio: $0.189 ; 95 \%$ CI: $0.078-0.457$; $P$-value for CL: $<0.01$.

${ }^{3}$ Least squares means for number of CL per treatment.

Figure 5). Nonpregnant cows of the Resynch treatment had a timely synchronized decrease in progesterone between 24 to $26 \mathrm{~d}$ after TAI. In contrast, CL regression, formation of a new CL, and subsequent increases in progesterone occurred at different times between 18 and $30 \mathrm{~d}$ for the control treatment such that there was no clear synchronized pattern of ovulation compared with the Resynch group.

\section{DISCUSSION}

Supplemental progesterone via a CIDR insert between d 18 and 25 after the preenrollment TAI and injection of GnRH at removal of the CIDR insert for resynchronization did not affect pregnancy per TAI for the preenrollment or pregnancy loss between d 32 and 60 of gestation compared with the control treatment. Overall pregnancy per AI to the Presynch + Ovsynch 56 -h protocol (45.9\%) and subsequent pregnancy losses to preenrollment $(5.4 \%)$ were considered good for a large commercial dairy herd. In comparison, Santos et al. (2009) reported an average of $38.3 \%(\mathrm{n}=6,396)$ for first service pregnancy per AI in herds using a TAI program.

The effect of progesterone supplementation with a CIDR insert on pregnancy per AI was evaluated in a series of studies. Treatment using a CIDR insert from d 14 to 21 after insemination was associated with a $4 \%$

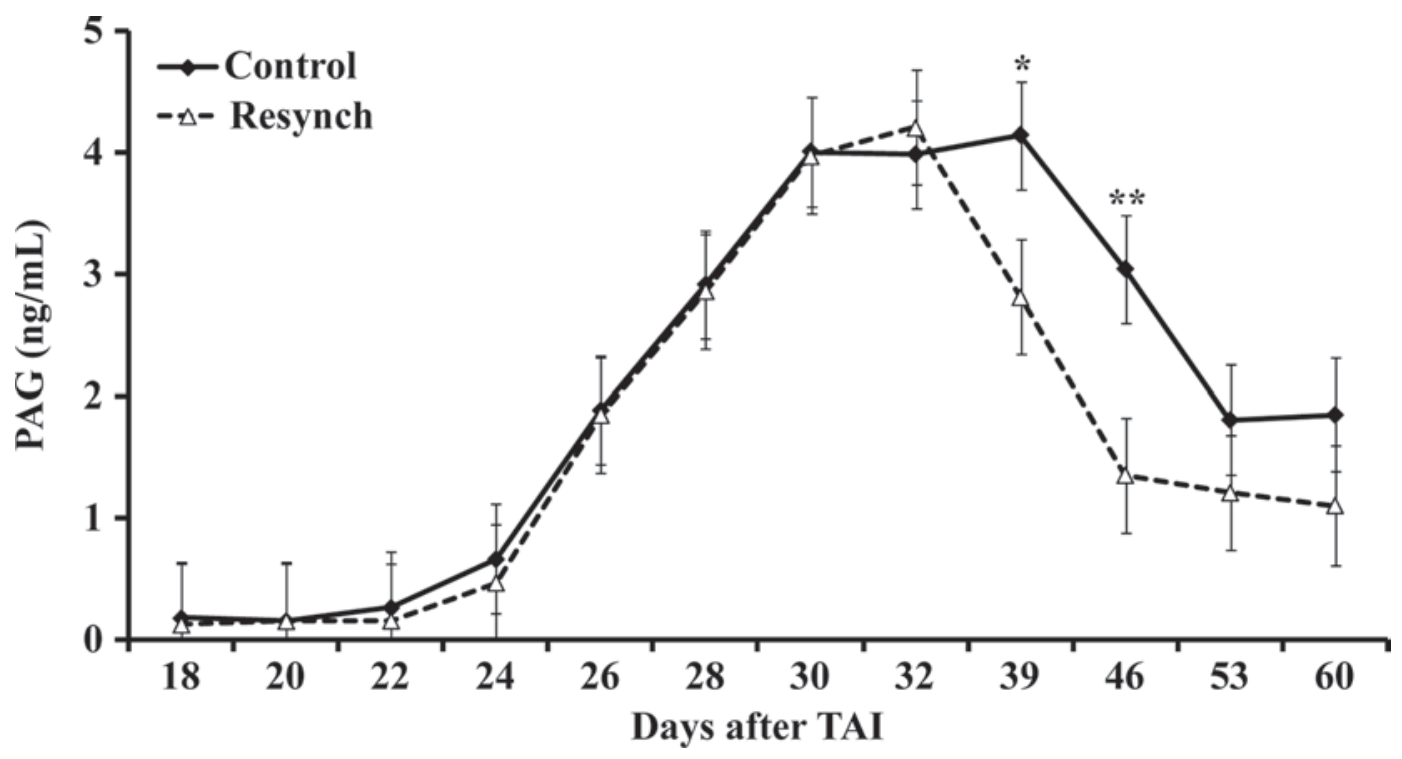

Figure 2. Plasma concentrations $(\mathrm{ng} / \mathrm{mL}$ ) of pregnancy-associated glycoproteins (PAG) in pregnant cows from d 18 to 60 of pregnancy for the control $(\mathrm{n}=23)$ and Resynch $(\mathrm{n}=20)$ treatments. Significant differences were detected on $\mathrm{d} 39(* P<0.04)$ and $46(* * P<0.01)$ of pregnancy. The LSM \pm SEM for PAG plasma concentrations for control and Resynch treatments were $2.06 \pm 0.25 \mathrm{and} 1.68 \pm 0.27 \mathrm{ng} / \mathrm{mL}$, respectively. TAI $=$ timed AI 
Table 5. Effect of resynchronization treatments on the presence of corpus luteum (CL) of nonpregnant cows at the time of first service pregnancy diagnosis on $\mathrm{d} 32$ after AI

\begin{tabular}{lcccc}
\hline Treatment $^{1}$ & $\begin{array}{c}\text { No CL, } \\
\%(\mathrm{n})\end{array}$ & $\begin{array}{c}\text { CL }{ }^{2} \\
\%(\mathrm{n})\end{array}$ & $\mathrm{Mean}^{3}$ & $\begin{array}{c}\text { Total } \\
\text { cows (n) }\end{array}$ \\
\hline Control & $26.6(110)$ & $73.3(303)$ & 0.73 & 413 \\
Resynch & $19.9(88)$ & $80.0(353)$ & 0.80 & 441 \\
\hline
\end{tabular}

${ }^{1}$ Control treatment: nonpregnant cows began an Ovsynch protocol on d 32 after first TAI followed by an intramuscular injection of $\mathrm{PGF}_{2 \alpha}$ on d 39 after TAI, a GnRH injection $56 \mathrm{~h}$ later, and TAI $72 \mathrm{~h}$ after $\mathrm{PGF}_{2 \alpha}$. Resynch treatment: cows received a controlled internal drug releasing device containing progesterone (CIDR) inserted for $7 \mathrm{~d}$ starting on d 18 after TAI and began an Ovsynch protocol beginning on d 25 at the time of CIDR removal. Only nonpregnant cows completed the protocol following a $\mathrm{PGF}_{2 \alpha}$ injection on d 32 after TAI, a GnRH injection $56 \mathrm{~h}$ later, and TAI $72 \mathrm{~h}$ after $\mathrm{PGF}_{2 \alpha}$.

${ }^{2} \mathrm{CL}(\mathrm{CL}$ vs. no $\mathrm{CL}) \times$ treatment interaction; odds ratio: $0.687 ; 95 \%$ CI: $0.499-0.945 ; P$-value for no CL: $<0.02$.

${ }^{3}$ Least squares means for number of CL per treatment.

reduction in pregnancy per $\mathrm{AI}$ to the preenrollment $\mathrm{AI}$ (Chenault et al., 2003). The CIDR inserts improved synchrony of return to estrus and did not affect pregnancy per AI during the resynchronization period. In contrast, Galvão et al. (2007) reported that the insertion of a CIDR for resynchronization between d 14 and 21 postinsemination with or without estradiol injection at the time of CIDR removal did not affect pregnancy rate or embryonic or fetal attrition. Moreover, Bartolome et al. (2009) documented that the use of a CIDR insert between d 14 and 23 after AI did not affect pregnancy outcome to the preenrollment AI and did not improve second service pregnancy per AI. In addition, no differences in pregnancy loss between 30 and $55 \mathrm{~d}$ for second service were detected between cows receiving a CIDR insert for resynchronization compared with control cows. In a meta-analysis, Mann and Lamming (1999) observed that supplementation of progesterone before $\mathrm{d}$ 6 after AI in lactating cows significantly increased pregnancy per AI. In addition, a reduction in pregnancy loss between d 31 and 60 of gestation was attributed to insertion of a CIDR insert between d 14 and 21 after first AI (Chebel et al., 2006). Although various studies are conflicting, the present results agree with Galvão et al. (2007) and Bartolome et al. (2009), indicating that insertion of a CIDR in early pregnancy between 14 to $18 \mathrm{~d}$ for a 7 -d period did not improve pregnancy per $\mathrm{AI}$ or reduce pregnancy loss in the preenrollment and resynchronized AI. Indeed, overall pregnancy losses in the present study were low (i.e., $\leq 6.7 \%$ ).

Reproductive performance is linked to health in the weeks immediately before and after calving, and timely achievement of subsequent pregnancy in turn has a substantial effect on profitability (De Vries, 2006b). Chebel et al. (2004) have associated reproductive success with periparturient diseases, and several studies revealed reductions in fertility for cows affected by disorders of the reproductive tract (LeBlanc, 2008), lameness, mastitis, and metabolic disorders (Opsomer et al., 2000; Schrick et al., 2001; Garbarino et al., 2004). In agreement with

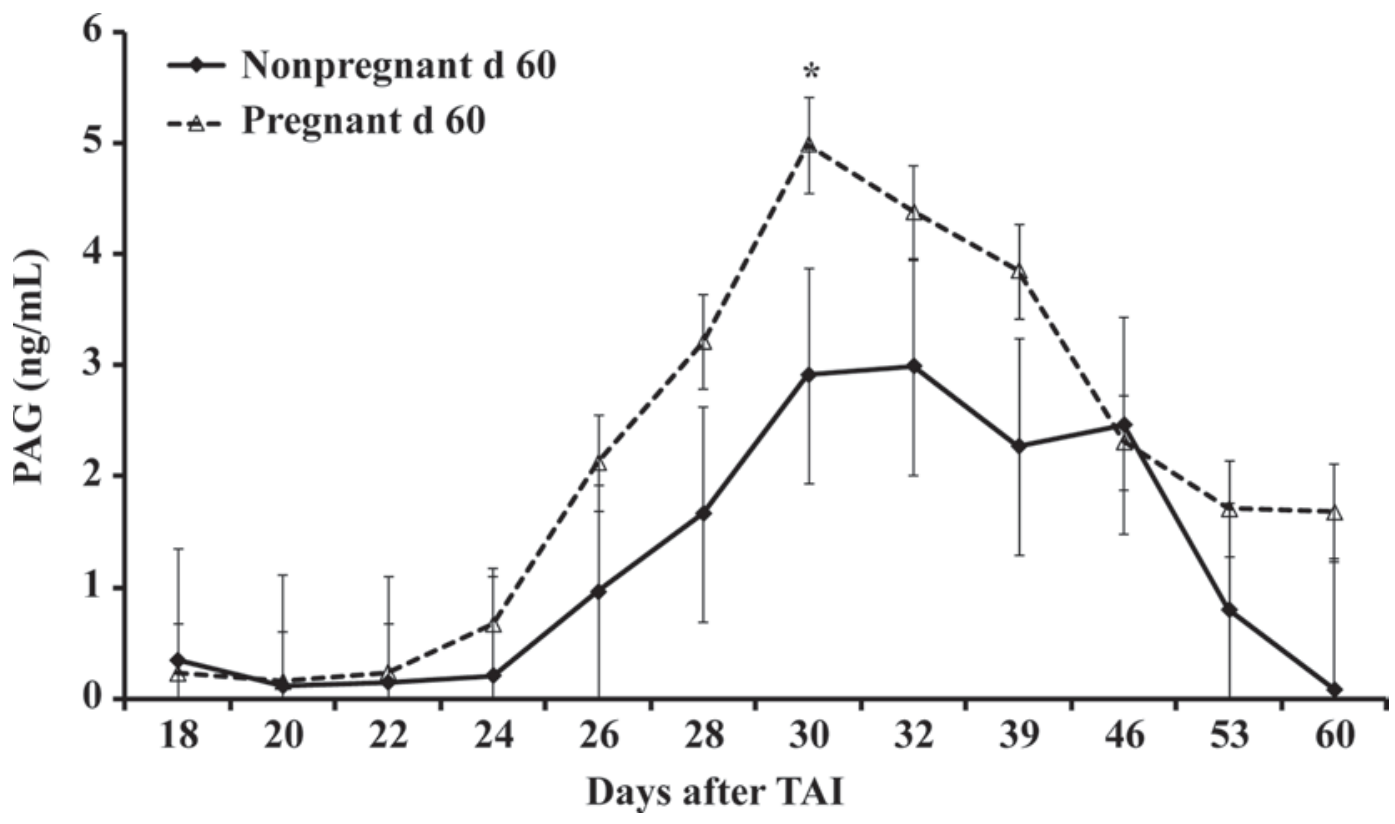

Figure 3. Pregnancy-associated glycoproteins (PAG) concentrations of cows $(n=36)$ that maintained their pregnancy until d 60 after timed AI (TAI) and cows $(\mathrm{n}=7)$ that had pregnancy loss. Cows that experienced pregnancy loss by d 60 after TAI had lesser $(* P<0.05)$ concentrations of PAG on d 30 after TAI compared with cows that maintained pregnancy (2.91 $\pm 0.96 \mathrm{vs} .4 .98 \pm 0.42 \mathrm{ng} / \mathrm{mL})$. The overall LSM \pm SEM for PAG plasma concentrations for cows that maintained and lost pregnancy were $2.12 \pm 0.24$ and $1.24 \pm 0.54 \mathrm{ng} / \mathrm{mL}$, respectively. 


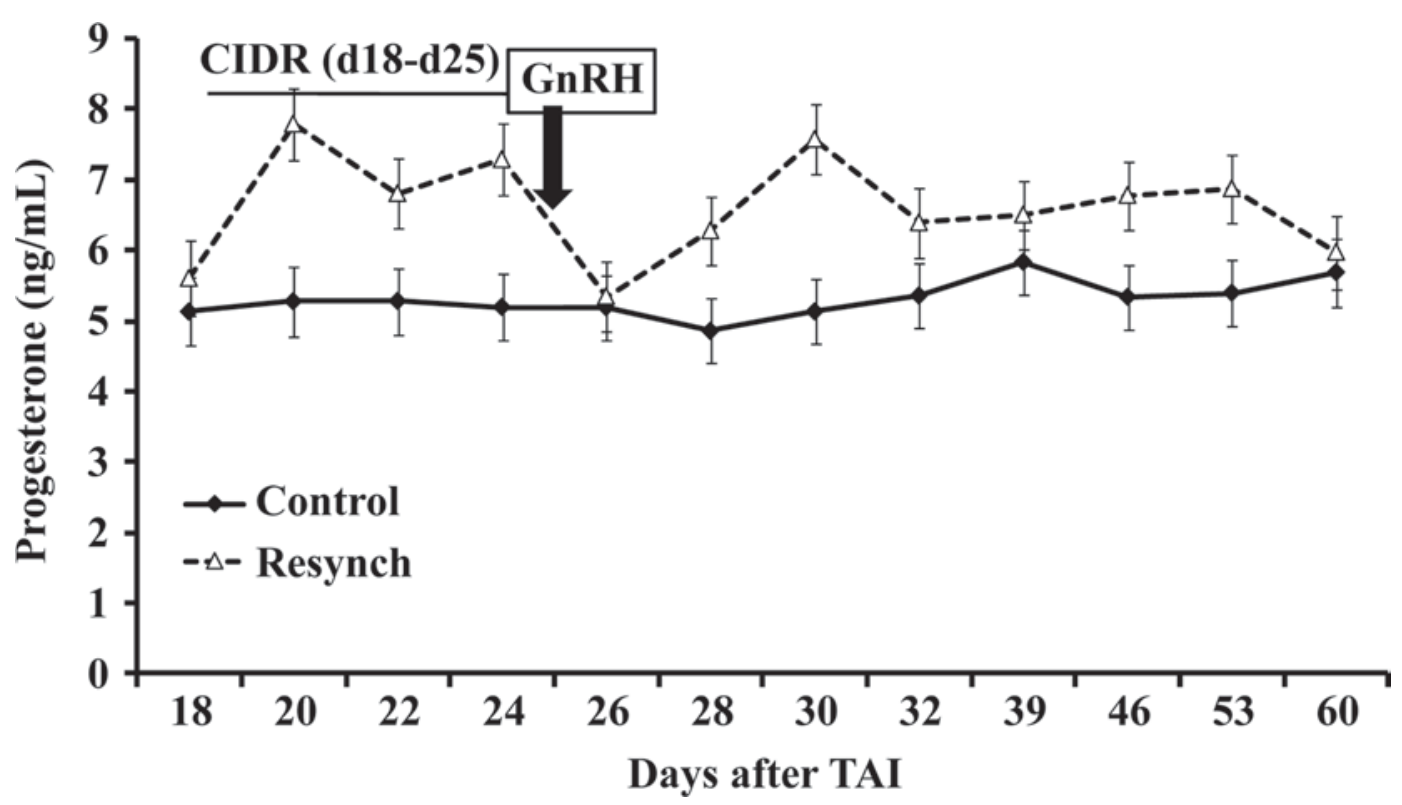

Figure 4. Profiles of progesterone plasma concentrations $(\mathrm{ng} / \mathrm{mL})$ of pregnant cows from d 18 to 60 of pregnancy in the control $(\mathrm{n}=23)$ and Resynch $(\mathrm{n}=20)$ treatments. Cows in the Resynch treatment maintained greater plasma progesterone concentrations $(P<0.003)$. The LSM \pm SEM for progesterone plasma concentrations for control and Resynch treatments were $5.30 \pm 0.28$ and $6.59 \pm 0.30 \mathrm{ng} / \mathrm{mL}$, respectively. Cows in the Resynch treatment were treated with a controlled internal drug releasing insert (CIDR) from d 18 to 25 after AI followed by a GnRH injection at the time of CIDR removal (d 25). Nonpregnant cows in the control treatment received a GnRH injection on $\mathrm{d} 32$ of pregnancy.

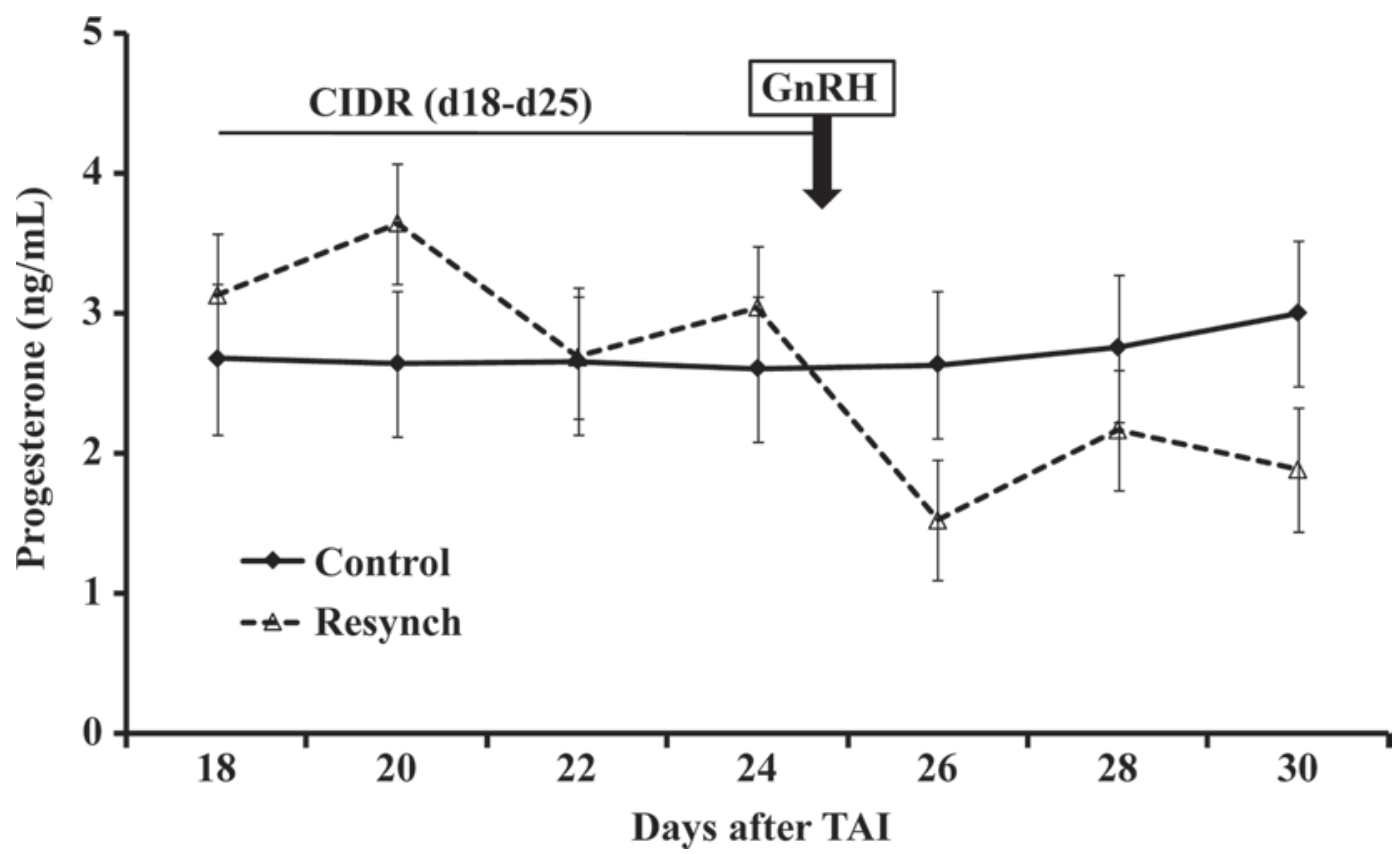

Figure 5. Profiles of progesterone plasma concentrations $(\mathrm{ng} / \mathrm{mL})$ of nonpregnant cows from d 18 to 30 of pregnancy of the control $(\mathrm{n}=23)$ and Resynch $(\mathrm{n}=34)$ treatments. No differences in plasma progesterone concentrations were detected between treatments; however, a treatment $x$ day interaction was detected $(P<0.03)$. The LSM \pm SEM for progesterone plasma concentrations of nonpregnant cows for control and Resynch treatments were $2.71 \pm 0.36$ and $2.57 \pm 0.29 \mathrm{ng} / \mathrm{mL}$, respectively. Cows in the Resynch treatment were treated with a controlled internal drug releasing insert (CIDR) from d 18 to 25 after AI followed by a GnRH injection at the time of CIDR removal (d 25). Nonpregnant cows in the control treatment received a GnRH injection on d 32 of pregnancy. 
previous studies, our results indicate that the occurrence of digestive problems, mastitis, dystocia, and retained fetal membranes decreased pregnancy per AI.

Use of exogenous progesterone promoted induction of cyclicity and better synchronization of estrus in lactating cows (Rhodes et al., 2003). Examination of ovarian structures of a subsample of Resynch and control cows at the time of $\mathrm{GnRH}$ and $\mathrm{PGF}_{2 \alpha}$ injections showed clear differences in ovarian structures between the 2 treatments. Cows in the Resynch treatment had a lesser occurrence of CL at the time of $\mathrm{GnRH}$ injection compared with cows in the control treatment. Likewise, cows with the CIDR insert had a greater percentage of large follicles. During the period of spontaneous CL regression between 18 and $25 \mathrm{~d}$, presence of a CIDR insert likely sustained follicle growth and blocked ovulation such that at the time the CIDR insert was removed and $\mathrm{GnRH}$ was injected, a sustained large dominant preovulatory follicle was present. The active dominance of this follicle accounted for the lesser number of medium and small follicles in the Resynch group. In contrast, nonpregnant cows of the control treatment likely had undergone spontaneous CL regression and a normal preovulatory follicle developed and ovulated. Consequently, a developing first wave follicle would be present at the time GnRH was injected on d 32. This likely accounted for a greater frequency of CL and medium follicles (i.e., $10-15 \mathrm{~mm}$ ) in nonpregnant control cows on d 32 .

Maintenance of a large follicle in the presence of a progestin has been well documented (Sirois and Fortune, 1990; Savio et al., 1993a,b). Clearly, differences in ovarian dynamics were detected between treatments that were further verified at the time of $\mathrm{PGF}_{2 \alpha}$ injection. The GnRH injection on d 25 for the Resynch treatment seemed to induce a greater synchronization of large follicles than the control treatment. This is suggested based on equal frequency of CL at $\mathrm{PGF}_{2 \alpha}$ injection but a smaller percentage of CL with large follicles compared with the control treatment. Follicle development would have been better synchronized in response to GnRH of the Resynch treatment, resulting in synchronized occurrence of medium follicles and a lesser synchronization of follicle development in the control treatment, with a wider array of ovulatory and nonovulatory follicles at the time of $\mathrm{GnRH}$ injection. Consequently, a greater number of control cows had a CL and large follicle at the time of $\mathrm{PGF}_{2 \alpha}$ injection. Although ovarian dynamics were distinctly different for the Resynch and control treatments approaching the second TAI, there were no significant differences in pregnancy per AI or pregnancy loss between treatments.

A reduction in the interval between first and second services has been the stimulus for the development of different resynchronization strategies (Chebel et al., 2003; Fricke et al., 2003; Bartolome et al., 2005c). Resynchronization programs are normally used in dairy herds as a reproductive management tool to improve the reinsemination rate of nonpregnant cows and reduce the interval from diagnosis of nonpregnancy to conception (Caraviello et al., 2006). An increase in the number of days between calving and conception (i.e., days open) is typically associated with reduced profitability, partly because of increased breeding cost, increased risk of culling and replacement costs, and reduced milk production (De Vries, 2006a). The Resynch treatment with a CIDR insert administered 1 wk preceding initiation of the Ovsynch protocol did not compromise fertility when the Ovsynch protocol was implemented 1 wk earlier than the control treatment (i.e., d 25 vs. d 32 after the first TAI). Days open was reduced by 3.2 $\mathrm{d}$ in the Resynch treatment because inseminations in the Resynch treatment began $7 \mathrm{~d}$ before those in the control treatment. De Vries (2006a) calculated costs per extra day open in the United States and estimated a variation from $\$ 3.19$ to $\$ 5.41$ per cow per year. With a total of 814 Resynch cows, the cost of using a CIDR insert from d 18 to 25 after $\mathrm{AI}$ and a GnRH injection at the time of CIDR removal was estimated as $\$ 8,359$ (i.e., $\mathrm{CIDR}=\$ 8.43$ and $\mathrm{GnRH}$ injection $=\$ 1.84)$. In addition, Resynch cows diagnosed nonpregnant $(\mathrm{n}=441)$ on d 32 were resynchronized receiving a $\mathrm{PGF}_{2 \alpha}$ (i.e., $\$ 2.03$ ) and a GnRH injection, which had an additional cost of $\$ 1,706$. Thus, the total cost for the use of a CIDR insert and a GnRH injection and the resynchronization program used for the Resynch treatment were estimated to be $\$ 10,065$. The number of pregnant cows in the Resynch treatment $(\mathrm{n}=532)$ multiplied by the estimate of fewer total days open (i.e., $3.2 \mathrm{~d}$; $\$ 3.19 /$ cow per day) detected in the Resynch treatment resulted in a savings of $\$ 5,430$, which when subtracted from the total cost gives a net cost estimate of $\$ 4,635$, or $\$ 8.71$ per pregnant cow. Control cows diagnosed not pregnant (413) were resynchronized with a $\mathrm{GnRH}$ injection on d $32, \mathrm{PGF}_{2 \alpha}$ injection on $\mathrm{d} 39$, and a subsequent $\mathrm{GnRH}$ injection $56 \mathrm{~h}$ later. Resynchronization of control cows had a total cost of $\$ 2,358$, or $\$ 4.59$ per pregnant cow. With these estimations, there was no benefit of using a CIDR insert and a GnRH injection for all cows in an earlier resynchronization program, which reduced days open. Resynch cows had a greater cost than control cows ( $\$ 8.71$ vs. $\$ 4.59 /$ ultimate pregnant cow).

Early assessment of pregnancy status and fetal viability identifies cows that fail to conceive and allows for an improvement in reproductive efficiency by possibly decreasing the interval between AI. The combination of ultrasound technology with new reproductive technologies, such as chemical diagnosis of early pregnancy, 
will provide additional tools for further development of integrated reproductive management systems (Fricke, 2002). The measurement of PAG in maternal blood at the time of early implantation of the conceptus is used as the basis for pregnancy diagnosis in cattle (Zoli et al., 1992; Green et al., 2005; Silva et al., 2007). The ELISA assay used in the present study was effective in identifying pregnant cows on d 30 of pregnancy with a sensitivity and specificity of 100 and $90.6 \%$, respectively. Overall mean concentrations of PAG in plasma did not differ between pregnant cows of the Resynch and control groups. Plasma concentrations of PAG increased beginning at approximately $24 \mathrm{~d}$, peaked at approximately $30 \mathrm{~d}$, and underwent a decline that occurred $1 \mathrm{wk}$ earlier in the Resynch group. Perhaps the slightly earlier decline of PAG in the Resynch treatment was attributable to increased progesterone from insertion of the CIDR insert and GnRH injection (Figure 4). The early increase and decrease of PAG in plasma has been reported in early pregnancy (Green et al., 2005) and is followed by a second phase increase throughout pregnancy to term. In cows diagnosed pregnant on $\mathrm{d}$ 32, LEM occurred in 7 cows between d 32 and 60 of gestation and they had lesser plasma concentrations of PAG on d 30 of pregnancy compared with cows that sustained their pregnancies to d 60. However, plasma concentrations of PAG were nondiscernable from $\mathrm{d}$ 37 to 60 during the descending phase of PAG in cows experiencing LEM and those that maintained a pregnancy. Lesser concentrations of PAG in plasma of pregnant cows on d 30 may be a predictor of LEM. This is in accordance with a series of studies reporting that measurement of plasma concentrations of PAG during pregnancy can most likely reflect fetal well-being (Patel et al., 1995; Kornmatitsuk et al., 2002; Szenci et al., 2003). In addition, Scenzi et al. (2003) reported that in cows diagnosed with LEM, both bovine pregnancyspecific protein B and bovine pregnancy-associated glycoprotein 1 concentrations started to decrease whereas the CL still produced progesterone. In addition, on d 30 of pregnancy, the ELISA test used for the measurement of plasma PAG concentrations for diagnosis of pregnancy had a sensitivity and specificity of 100 and $90.6 \%$, respectively, when cows with plasma concentrations $>0.33 \mathrm{ng} / \mathrm{mL}$ were considered pregnant. The sensitivity indicated that $100 \%$ of the cows diagnosed as pregnant on $\mathrm{d} 30$ by plasma PAG concentrations were confirmed pregnant by ultrasound on d 32. Moreover, $90.6 \%$ of the cows diagnosed nonpregnant by ultrasound on $\mathrm{d} 32$ were detected as nonpregnant by plasma PAG concentrations on $\mathrm{d} 30$. Thus, $9.4 \%$ of the cows checked nonpregnant on d 32 by ultrasound were diagnosed as pregnant on d 30 by the measurement of plasma PAG concentrations. Consequently, these cows $(9.4 \%)$, in the present experiment, would not have been treated with $\mathrm{PGF}_{2 \alpha}$ until diagnosed nonpregnant by ultrasound (d 32) for the Resynch treatment or would not have started a resynchronization program with $\mathrm{GnRH}$ in the control treatment.

The role of PAG during pregnancy has not been elucidated to date. In the present study, in a subsample of 103 cows sampled for measurement of PAG on the day of parturition, concentrations were related only to sex of calf, with maternal plasma PAG being greater in cows bearing a male calf. This is likely attributed to greater size of male calves, which reflected a possibly larger placental-fetal unit that secreted greater amounts of PAG throughout pregnancy. Others have reported greater concentrations of PAG associated with male fetuses (Zoli et al., 1992).

Previous studies documented that progesterone supplementation after AI reduced pregnancy loss (ElZarkouny and Stevenson, 2004; Chebel et al., 2006). Therefore, supplementation of progesterone after AI might benefit pregnancy in lactating dairy cows. Interestingly, in the present study, there were no differences in pregnancy per AI and pregnancy loss between cows that received a CIDR insert and control cows. The mean increase in plasma concentrations of progesterone in lactating dairy cows following insertion of a CIDR device was approximately $0.8 \mathrm{ng} / \mathrm{mL}$ (Cerri et al., 2009), and that might not have been enough to significantly increase pregnancy per AI or reduce pregnancy loss in the Resynch treatment. In contrast, cows that received a CIDR insert and a GnRH injection maintained plasma progesterone concentrations greater even after the removal of the progesterone insert. The slightly sustained concentrations of progesterone during the perimplantation period may attenuate LEM and such a benefit may have been achieved with only a GnRH injection on d 32 in the control treatment. The present experiment did not have an experimental treatment of pregnant cows that did not receive an injection of GnRH to examine LEM. On a relative basis, overall pregnancy losses were low (i.e., 5.4\%) for preenrollment pregnancies compared with $12.8 \%$ summarized across numerous studies (Santos et al., 2004).

\section{CONCLUSIONS}

Although distinct differences in CL and follicle development were observed between treatments, use of progesterone supplementation neither influenced pregnancy per AI for first and second TAI services nor improved embryo survival. Progesterone concentrations were greater in the Resynch treatment for pregnant cows. Fewer total days open occurred in the Resynch treatment because of reinsemination $7 \mathrm{~d}$ earlier at a cost 
of $\$ 8.39$ per ultimate pregnant cow. The present study reinforced that different health occurrences observed during the postpartum period decreased pregnancy per AI to first TAI service and emphasizes the importance of transition cow management. Concentrations of PAG did not differ between treatments, although cows experiencing LEM had lesser concentrations of PAG on d 30 of pregnancy. Plasma concentration of PAG on the day of parturition was greater for cows that delivered male calves. Measurement of PAG on d 28 or 30 was a sensitive and specific predictor of pregnancy on d 32 as determined by ultrasonography.

\section{ACKNOWLEDGMENTS}

The authors thank Pfizer Animal Health (New York, NY) for partial grant support to conduct the study. Our gratitude also is extended to the owner of Alliance Dairies (Trenton, FL), Ronald St. John, for use of the dairy herd, and the entire staff of Alliance Dairies for their assistance with this study. Assistance of Tina Parks (University of Missouri) with the ELISA assay for PAG is appreciated.

\section{REFERENCES}

Bartolome, J. A., F. T. Silvestre, S. Kamimura, A. C. M. Arteche, P. Melendez, D. Kelbert, J. McHale, K. Swift, L. F. Archbald, and W. W. Thatcher. 2005a. Resynchronization of ovulation and timed insemination in lactating dairy cows I: Use of the Ovsynch and Heatsynch protocols after non-pregnancy diagnosis by ultrasonography. Theriogenology 63:1617-1627.

Bartolome, J. A., A. Sozzi, J. McHale, P. Melendez, A. C. M. Arteche, F. T. Silvestre, D. Kelbert, K. Swift, L. F. Archbald, and W. W. Thatcher. 2005b. Resynchronization of ovulation and timed insemination in lactating dairy cows, II: Assigning protocols according to stages of the estrous cycle, or presence of ovarian cysts or anestrus. Theriogenology 63:1628-1642.

Bartolome, J. A., A. Sozzi, J. McHale, K. Swift, D. Kelbert, L. F. Archbald, and W. W. Thatcher. 2005c. Resynchronization of ovulation and timed insemination in lactating dairy cows III. Administration of $\mathrm{GnRH} 23$ days post $\mathrm{AI}$ and ultrasonography for nonpregnancy diagnosis on day 30. Theriogenology 63:16431658.

Bartolome, J. A., J. J. J. Van Leeuwen, M. Thieme, O. G. Sá Filho, P. Melendez, L. F. Archbald, and W. W. Thatcher. 2009. Synchronization and resynchronization of inseminations in lactating dairy cows with the CIDR insert and the Ovsynch protocol. Theriogenology 72:869-878.

Caraviello, D. Z., K. A. Weigel, P. M. Fricke, M. C. Wiltbank, M. J. Florent, N. B. Cook, K. V. Nordlund, N. R. Zwald, and C. L. Rawson. 2006. Survey of management practices on reproductive performance of dairy cattle on large US commercial farms. J. Dairy Sci. 89:4723-4735.

Cerri, R. L. A., H. M. Rutigliano, R. G. S. Bruno, and J. E. P. Santos. 2009. Progesterone concentration, follicular development and induction of cyclicity in dairy cows receiving intravaginal progesterone inserts. Anim. Reprod. Sci. 110:56-70.

Chebel, R. C., J. E. P. Santos, R. L. A. Cerri, K. N. Galvão, S. O. Juchem, and W. W. Thatcher. 2003. Effect of resynchronization with GnRH on day 21 after artificial insemination on pregnancy rate and pregnancy loss in lactating dairy cows. Theriogenology 60:1389-1399.
Chebel, R. C., J. E. P. Santos, R. L. A. Cerri, H. M. Rutigliano, and R. G. S. Bruno. 2006. Reproduction in dairy cows following progesterone insert presynchronization and resynchronization protocols. J. Dairy Sci. 89:4205-4219.

Chebel, R. C., J. E. P. Santos, J. P. Reynolds, R. L. A. Cerri, S. O. Juchem, and M. Overton. 2004. Factors affecting conception rate after artificial insemination and pregnancy loss in lactating dairy cows. Anim. Reprod. Sci. 84:239-255.

Chenault, J. R., J. F. Boucher, K. J. Dame, J. A. Meyerand, and S. L. Wood-Follis. 2003. Intravaginal progesterone insert to synchronize return to estrus of previously inseminated dairy cows. J. Dairy Sci. 86:2039-2049.

De Vries, A. 2006a. Economic value of pregnancy in dairy cattle. J. Dairy Sci. 89:3876-3885.

De Vries, A. 2006b. Determinants of the cost of days open in dairy cattle. Page 1114 in Proceedings of the 11th Symposium of the International Society for Veterinary Epidemiology and Economics, Cairns, Australia. International Society for Veterinary Epidemiology and Economics, Cairns, Australia.

El-Zarkouny, S. Z., and J. S. Stevenson. 2004. Resynchronizing estrus with progesterone or progesterone plus estrogen in cows of unknown pregnancy status. J. Dairy Sci. 87:3306-3321.

Fricke, P. M. 2002. Scanning the future-Ultrasonography as a reproductive management tool for dairy cattle. J. Dairy Sci. 85:1918-1926.

Fricke, P. M., D. Z. Caraviello, K. A. Weigeland, and M. L. Welle. 2003. Fertility of dairy cows after resynchronization of ovulation at three intervals following first timed insemination. J. Dairy Sci. 86:3941-3950.

Gábor, G., F. Tóth, L. Ozsvári, Z. Abonyi-Tóth, and R. G. Sasser. 2007. Early detection of pregnancy and embryonic loss in dairy cattle by ELISA tests. Reprod. Domest. Anim. 42:633-636.

Galvão, K. N., J. E. P. Santos, R. L. A. Cerri, R. C. Chebel, H. M. Rutigliano, R. G. Bruno, and R. C. Bicalho. 2007. Evaluation of methods of resynchronization for insemination in cows of unknown pregnancy status. J. Dairy Sci. 90:4240-4252.

Garbarino, E. J., J. A. Hernandez, J. K. Shearer, C. A. Risco, and W. W. Thatcher. 2004. Effect of lameness on ovarian activity in postpartum Holstein cows. J. Dairy Sci. 87:4123-4131.

Green, J. A., T. E. Parks, M. P. Avalle, B. P. Telugu, A. L. McLain, A. J. Peterson, W. McMillan, N. Mathialagan, R. R. Hook, S. Xie, and R. M. Roberts. 2005. The establishment of an ELISA for the detection of pregnancy-associated glycoproteins (PAGs) in the serum of pregnant cows and heifers. Theriogenology 63:14811503.

Green, J. A., and R. M. Roberts. 2006. Establishment of an ELISA for the detection of native bovine pregnancy-associated glycoproteins secreted by trophoblast binucleate cells. Methods Mol. Med. 122:321-330.

Kornmatitsuk, B., M. C. Veronesi, A. Madej, E. Dahl, E. Ropstad, J. F. Beckers, M. Forsberg, H. Gustafsson, and H. Kindahl. 2002. Hormonal measurements in late pregnancy and parturition in dairy cows-Possible tools to monitor foetal well being. Anim. Reprod. Sci. 72:153-164.

LeBlanc, S. J. 2008. Postpartum uterine disease and dairy herd reproductive performance: A review. Vet. J. 176:102-114.

Mann, G. E., and G. E. Lamming. 1999. The influence of progesterone during early pregnancy in cattle. Reprod. Domest. Anim. 34:269 274.

Moreira, F., C. Orlandi, C. A. Risco, R. Mattos, F. Lopesand, and W. W. Thatcher. 2001. Effects of presynchronization and bovine somatotropin on pregnancy rates to a timed artificial insemination protocol in lactating dairy cows. J. Dairy Sci. 84:1646-1659.

NRC. 2001. Nutrient Requirements of Dairy Cattle. 7th ed. Natl. Acad. Sci., Washington, DC.

Opsomer, G., Y. T. Gröhn, J. Hertl, M. Coryn, H. Deluyker, and A. de Kruif. 2000. Risk factors for post partum ovarian dysfunction in high producing dairy cows in Belgium: A field study. Theriogenology $53: 841-857$.

Patel, O. V., I. Domeki, N. Sasaki, T. Takahashi, M. Hirako, R. G. Sasser, and P. Humblot. 1995. Effect of fetal mass, number and 
stage of gestation on pregnancy-specific protein B concentrations in the bovine. Theriogenology 44:827-833.

Patel, O. V., J. Sulon, J. F. Beckers, T. Takahashi, M. Hirako, N. Sasaki, and I. Domeki. 1997. Plasma bovine pregnancy-associated glycoprotein concentrations throughout gestation in relationship to fetal number in the cow. Eur. J. Endocrinol. 137:423-428.

Pursley, J. R., M. C. Wiltbank, J. S. Stevenson, J. S. Ottobre, H. A. Garverick, and L. L. Anderson. 1997. Pregnancy rates per artificial insemination for cows and heifers inseminated at a synchronized ovulation or synchronized estrus. J. Dairy Sci. 80:295-300.

Rhodes, F. M., S. McDougall, C. R. Burke, G. A. Verkerkand, and K. L. Macmillan. 2003. Invited review: Treatment of cows with an extended postpartum anestrous interval. J. Dairy Sci. 86:18761894.

Santos, J. E. P., H. M. Rutigliano, and M. S. Sá Filho. 2009. Risk factors for resumption of postpartum estrous cycles and embryonic survival in lactating dairy cows. Anim. Reprod. Sci. 110:207221.

Santos, J. E. P., W. W. Thatcher, R. C. Chebel, R. L. A. Cerri, and K. N. Galvão. 2004. The effect of embryonic death rates in cattle on the efficacy of estrus synchronization programs. Anim. Reprod. Sci. 82-83:513-535.

Sasser, R. G., C. A. Ruder, K. A. Ivani, J. E. Butler, and W. C. Hamilton. 1986. Detection of pregnancy by radioimmunoassay of a novel pregnancy-specific protein in serum of cows and a profile of serum concentrations during gestation. Biol. Reprod. 35:936942.

Savio, J. D., W. W. Thatcher, L. Badinga, R. L. de la Sota, and D. Wolfenson. 1993a. Regulation of dominant follicle turnover during the oestrous cycle in cows. J. Reprod. Fertil. 97:197-203.
Savio, J. D., W. W. Thatcher, G. R. Morris, K. Entwistle, M. Drost, and M. R. Mattiacci. 1993b. Effects of induction of low plasma progesterone concentrations with a progesterone-releasing intravaginal device on follicular turnover and fertility in cattle. J. Reprod. Fertil. 98:77-84.

Schrick, F. N., M. E. Hockett, A. M. Saxton, M. J. Lewis, H. H. Dowlen, and S. P. Oliver. 2001. Influence of subclinical mastitis during early lactation on reproductive parameters. J. Dairy Sci. 84:1407-1412.

Silva, E., R. A. Sterry, D. Kolb, N. Mathialagan, M. F. McGrath, J. M. Ballam, and P. M. Fricke. 2007. Accuracy of a pregnancyassociated glycoprotein ELISA to determine pregnancy status of lactating dairy cows twenty-seven days after timed artificial insemination. J. Dairy Sci. 90:4612-4622.

Sirois, J., and J. E. Fortune. 1990. Lengthening the bovine estrous cycle with low levels of exogenous progesterone: A model for studying ovarian follicular dominance. Endocrinology 127:916-925.

Szenci, O., J. F. Beckers, J. Sulon, M. M. Bevers, L. Börzsönyi, L. Fodor, F. Kovács, and M. A. Taverne. 2003. Effect of induction of late embryonic mortality on plasma profiles of pregnancy associated glycoprotein 1 in heifers. Vet. J. 165:307-313.

Wooding, F. B. P., R. M. Roberts, and J. A. Green. 2005. Light and electron microscope immunocytochemical studies of the distribution of pregnancy associated glycoproteins (PAGs) throughout pregnancy in the cow: Possible functional implications. Placenta 26:807-827.

Zoli, A. P., L. A. Guilbault, P. Delahaut, W. B. Ortiz, and J. F. Beckers. 1992. Radioimmunoassay of a bovine pregnancy-associated glycoprotein in serum: Its application for pregnancy diagnosis. Biol. Reprod. 46:83-92. 